\title{
GEOCHEMISTRY OF INDICATOR MINERALS FROM CHINESE KIMBERLITES AND
} LAMPROITES.

\author{
Jianxiong Zhou ${ }^{(1)} ;$ W.L. Griffin ${ }^{(2)}$, A.L. Jaques ${ }^{(3)} ;$ C.G. Ryan ${ }^{(2)}$ and T.T. Win ${ }^{(2)}$. \\ (1) Institute of Mineral Deposits, CAGS, Beijing 100037, China; (2) SCIRO Div. of Exploration Geoscience, North \\ Ryde 2113, Australia; (3) Bureau of Mineral Resources, Canberra, 2601, Australia.
}

Over 900 grains of indicator minerals, including pyrope, chromite, ilmenite, LIMA and yimengite have been analyzed by EMP and proton microprobe. The bodies studied come from seven different provinces and include both diamondiferous and barren intrusives. The data show consistent patterns that can be used in exploration and evaluation of prospects within each area.

Kimberlites and lamproites have been found only in the Sino-Korean craton and the Yangzi craton, while similar bodies in the Talimu craton (Xinjiang Autonomous Region) have proven to be lamprophyres. Most studied bodies in the Sino-Korean craton are Group I kimberlites; some contain economic deposits of diamonds, while others are barren. The Yangzi craton contains both lamproites and possible Group II kimberlites; some contain low grades of diamonds. Among the indicator minerals, pyrope and chromite are very common, while ilmenite is rare, being restricted to kimberlites in Shandong and Liaoning. LIMA and yimengite are found in Shandong kimberlites, especially Hongqi No. 27.

The diamondiferous kimberlites of Liaoning and Shandong provinces contain abundant G9 garnets with $\mathrm{Cr}_{2} \mathrm{O}_{3}$ up to $11 \mathrm{wt}$.\%, and a significant number of moderately subcalcic pyropes. Barren kimberlites have, in general, higher proportions of low-Cr pyropes. Subcalcic garnets are rare in the lamproites, and the average $\mathrm{Cr}$ content of lamproite pyropes is lower than those from diamondiferous kimberlites. Garnets from the diamondiferous Liaoning kimberlites show a broad bimodal distribution of $\mathrm{T}_{\mathrm{Ni}}$ (Griffin et al., 1989a), with peaks centered on $950^{\circ} \mathrm{C}$ and $1150^{\circ} \mathrm{C}$ (Fig. 1a). There is a minor high-T group $\left(>1300^{\circ} \mathrm{C}\right)$ which is interpreted as megacryst-related, and is present mainly in the lower-grade pipes of the district. Most of the lower-T garnets are depleted, with $\mathrm{Y}<10 \mathrm{ppm}, \mathrm{Zr}<40 \mathrm{ppm}$ and $\mathrm{Zr} / \mathrm{Y} \sim 2-3$. Many grains have higher $\mathrm{Zr}$ (to $200 \mathrm{ppm}$ ) and high $\mathrm{Zr} / \mathrm{Y}$, without corresponding Ti enrichment. This pattern is interpreted as the effect of hydrous metasomatism. The Shandong garnets are characterized by much higher temperatures, with major peaks at $1150-1300^{\circ} \mathrm{C}$ and $1400-1550^{\circ} \mathrm{C}$ (Fig. 1b). The high-T peak is dominated by low-Cr, high-Zr, Y garnets, which are interpreted as megacryst-related. Many lherzolite garnets in the Shandong pipes are depleted, like those from Liaoning, but many others have elevated $\mathrm{Zr}$ and $\mathrm{Y}$, strongly correlated with $\mathrm{Ti}$; this is interpreted as the effect of melt-related metasomatism (Griffin et al, 1989b; Smith et al, 1991), associated with the observed megacryst population. The diamondiferous Maping No. 1 lamproite of Guizhou Province shows a broad T distribution from $1150-1300^{\circ} \mathrm{C}$; the higher-T part of the range is represented by megacryst-type garnets. The lherzolitic garnets from Guizhou are depleted, like those from Shandong and Liaoning.

Garnets from barren pipes in all districts are characterized by low- $\mathrm{T}$ garnets $\left(\mathrm{T}<1000^{\circ} \mathrm{C}\right)$, with a minor high-T population and a small proportion in the "diamond window" $\left(950-1250^{\circ} \mathrm{C}\right)$ (Fig. 1c). Even where temperatures above $950^{\circ} \mathrm{C}$ are recorded, the garnets retain the low- $\mathrm{Zr}$ $(\mathrm{Zr}<40 \mathrm{ppm})$, high-Y (Y>20ppm) signature typical of low-T, low-P garnets; the relatively high temperatures may reflect short-lived heating events, rather than the ambient geotherm (Smith et al., 1991). A plot of $\mathrm{Zr} / \mathrm{Y}^{-}$vs. Y/Ga (Fig. 2) clearly separates the garnets of the barren and diamondiferous pipes: nearly all garnets from barren pipes have $\mathrm{Zr} / \mathrm{Y}<1$ and $\mathrm{Y} / \mathrm{Ga}>2$.

The kimberlites of the Sino-Korean craton contain abundant high-Cr chromite macrocrysts; these can be divided into two populations (P1 and P2) on the basis of major- and

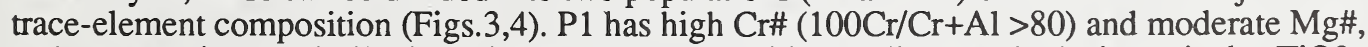
and some grains are similar in major-element composition to diamond-inclusion spinels. TiO2 ranges from $0-4 \%$, and is positively correlated with $\mathrm{Ni}$. P1 is typical of spinel macrocrysts in South African Group 1 kimberlites, and is derived largely from harzburgite and lherzolite wall 
rocks (Griffin et al., 1991). P2 has lower Cr\# and higher Mg\#; Ti and Ni contents are low, and $\mathrm{Zn}$ contents are high $(>1000 \mathrm{ppm})$. This population is probably derived from disaggregated lherzolites, in the graphite stability field (op. cit.). Diamondiferous kimberlites in the SinoKorean craton contain both populations; barren kimberlites contain only P2. The P1 population in the Shandong kimberlites has generally higher $\mathrm{Zn}$ and lower Ni than that in Liaoning province, suggesting that a higher proportion of the material in these pipes comes from the graphite stability field. Chromites from the barren Henan and Hebei kimberlites contain 50-60\% $\mathrm{Cr} 2 \mathrm{O} 3$, and have low Ti contents. However, only a few grains have the major-element/trace element relations of a typical kimberlitic population. Their low Ni and high Zn contents (Fig. 4) indicate that most grains have come from shallow, low-T lherzolites, in the graphite stability field.

Chromites from the Guizhou and Hubei lamproites are generally lower in $\mathrm{Cr}$ and $\mathrm{Zn}$, and higher in Ni than those from the kimberlites, regardless of their diamond content (Fig. 4). They are dominated by a population common to lamproites worldwide, and inferred to be magmatic (op. cit.); very few grains can be identified as being derived from lherzolite or harzburgite wall-rock. It is not possible to separate these diamondiferous and barren lamproites on the basis of chromite chemistry.

Ilmenites are clearly divided into two groups, one with low $\mathrm{MgO}$ and high $\mathrm{MnO}$ (>1\%), and one with high $\mathrm{Cr}_{2} \mathrm{O}_{3}(1-7 \%)$ and $\mathrm{MgO}$ (up to $16 \%$ ). The first type is found in eg. the Shengli No. 1 mine; it has low Nb, $\mathrm{Zr}$ and $\mathrm{Ni}$, and is clearly of crustal origin. The second type has been studied at the Hongqi No. 27 pipe; it does not show the smooth covariation of $\mathrm{Nb}, \mathrm{Ni}, \mathrm{Zr}$ etc. that characterizes most African and Siberian ilmenite megacryst populations. This, and the unusually high $\mathrm{Cr}$ contents, suggest a link to the LIMA association, rather than to fractionation of a megacryst-type magma.

This orientation study demonstrates that trace-element studies of garnets and chromites can be used in the Chinese cratons to improve diamond exploration by early discrimination of barren and potentially diamond-bearing sources. Barren sources sampled thus far all contain garnets and spinels derived from shallow levels of the mantle, rather than from the diamond stability field. The data also suggest significant differences in the thermal state of the lithosphere on either side of the major Tanlu suture. These differences may have broader implications for exploration strategies.

Griffin, W.L., Cousens, D.R., Ryan, C.G., Sie, S.H. and Suter, G.F. 1989a. Contrib. Mineral. Petrol. 103, 199-202.

Griffin, W.L., Smith, D., Boyd, F.R., Cousens, D.R., Ryan, C.G., Sie, S.H. and Suter, G.F. 1989b. Geochim. Cosmochim. Acta 53, 561-567.

Griffin, W.L., Ryan, C.G., Gurney, J.J., Sobolev, N.V. and Win, T.T., 1991. (this vol.) Smith, D., Griffin, W.L., Ryan, C.G. and Sie, S. 1.991. Contr. Mineral. Petrol., in press.

\section{FIGURES (next page)}

Fig. 1 (left). TNi histograms for diamondiferous kimberlites of Liaoning and Shandong provinces, and for barren kimberlites from Liaoning, Shanxi, Henan and Hebei provinces.

Fig. 2 (top right). Zr/Y - Y/Ga plot for garnets. Squares, barren kimberlites; circles, Liaoning diamondiferous kimberlites; stars, Shandong diamondiferous kimberlites.

Fig. 3 (middle right). Cr-Ni relations in chromites. Squares, diamondiferous kimberlites; circles, lamproites; stars, barren kimberlites.

Fig. 4 (lower right). Zn-Ni relations in chromites. Symbols as in Fig. 3. 

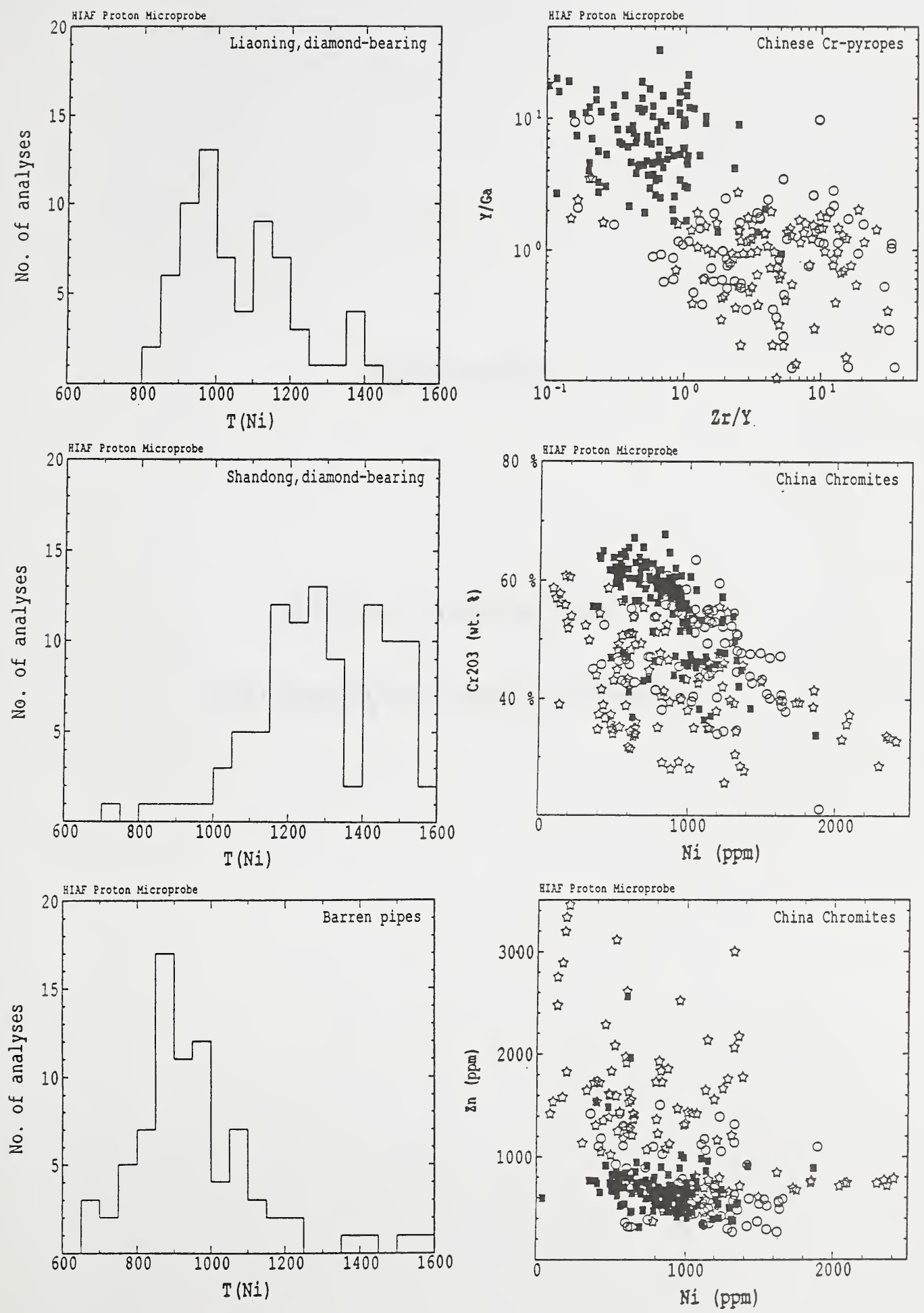